\title{
Correction to: Effect of Adjacent Support Condition on Premature Wood Crosstie Failure
}

\author{
Kenza Soufiane $^{1} \cdot$ Allan M. Zarembski $^{1} \cdot$ Joseph W. Palese ${ }^{1}$ \\ Published online: 21 July 2021 \\ (C) Springer Science+Business Media, LLC, part of Springer Nature 2021
}

\section{Correction: Transportation Infrastructure Geotechnology https://doi.org/10.1007/s40515-021-00168-5}

The original version of this article unfortunately contained a mistake in Table 2 . The second column of the last row exceeds the gutter. The correct Table 2 is shown here. The original article has been corrected.

Publisher's Note Springer Nature remains neutral with regard to jurisdictional claims in published maps and institutional affiliations.

The online version of the original article can be found at https://doi.org/10.1007/s40515-021-00168-5

\section{Kenza Soufiane}

kenzasou@udel.edu

Allan M. Zarembski

dramz@udel.edu

Joseph W. Palese

palesezt@udel.edu

1 Department of Civil and Environmental Engineering, University of Delaware, Newark, DE, USA 
Table 2 Average loss of support and tie configurations corresponding to each group

\begin{tabular}{|c|c|c|c|}
\hline Group & Configuration & $\begin{array}{l}\text { Average Loss } \\
\text { of support }(\%)\end{array}$ & $\begin{array}{l}\text { Number of ties } \\
\text { in the category }\end{array}$ \\
\hline $\mathrm{F}$ & & 0 & 77937 \\
\hline A & & 17 & 16379 \\
\hline B & & 33 & 1410 \\
\hline $\mathrm{C}$ & & 46 & 695 \\
\hline
\end{tabular}

